\title{
Stratigraphy of Kendeng Zone in Miyono Village and Surrounding Areas Sekar District, Bojonegoro Regency, East Java, Indonesia
}

\author{
Mutawif Ilmi Muwaffiqih;, Wahyu Ardiansyah Nugraha, Irvan Fatarwin Lubis, and Moch. \\ Indra Novian
}

Department of Geological Engineering, Faculty of Engineering, Universitas Gadjah Mada, Yogyakarta, Indonesia

\begin{abstract}
Geological history that develops in an area is very important to recognize the area. The stratigraphic analysis is one of the ways to find out that geological history. One of the interesting areas to research stratigraphy is Kendeng Zone. Miyono Village and surrounding areas, Sekar District, Bojonegoro Regency, belonged to Kendeng Zone and was chosen because it comprises well-preserved lithological and complex geological structures. The methods used in this stratigraphic analysis were stratigraphic and laboratory analysis. The stratigraphic analysis used 160 point stations to compile stratigraphic sections from the point stations truncated by the section lines. The laboratory analysis was used for petrographic and paleontological analysis. Based on the methods, the lithological units are divided into nine units within ages N18-N23 (early Pliocene - Holocene). The barren area's comparability column used the age from planktonic foraminifera, mostly Globorotalia and Globigerinoides. The depositional environment ranged from the lower bathyal to the terrestrial, from various benthonic foraminifera. The geological structure of the research area has a dominant Meratus pattern showing NW-SE main force trending direction. Based on the analysis, the stratigraphic column was obtained and expected to provide stratigraphic data of Miyono Village and the surrounding area in the Kendeng Zone.
\end{abstract}

Keywords: Stratigraphy · Kendeng Zone · Miyono · Bojonegoro Regency.

\section{INTRODUCTION}

Geological research is a series of fieldwork and laboratory work that compiles a geological map. The geological map itself is a map that shows a two-dimensional picture, a vertical projection of the overlay groups (units) of rocks on the earth's surface in an area, including the local structures' configuration. The geological map depicts all geological elements in the form of signs, symbols, or colors. Then, on the geological map, there will be a distribution of existing rock units and structures. Miyono Village and surrounding areas were chosen because it comprises well-preserved sedimen-

\footnotetext{
${ }^{*}$ Corresponding author: M.I. MuWAFFIQIH, Department of Geological Engineering, Universitas Gadjah Mada. Jl. Grafika 2 Yogyakarta, Indonesia. E-mail: mutawif.ilmi.muwaffiqih@mail.ugm.ac.id
}

tary rock and complex geological structures. This research's output is in maps and geological profiles, structural analysis, and detailed stratigraphic columns of the research area.

The research areas are in Miyono Village, Sekar Village, Bobol Village, Bareng Village, and Duren Village; Sekar District; Bojonegoro Regency; East Java Province, Indonesia (Figure 1). Based on the Indonesian Topographic Map (Blom Narcon Cooperation, 1999) scale $1: 25,000$, the research location is included in the Pilangkenceng map sheet number 1508512. Geographically, the research area is located approximately between $580000 \mathrm{~m}$ (western boundary) - 584000m (eastern boundary) and $9176000 \mathrm{~m}$ (southern boundary) - $9181000 \mathrm{~m}$ (northern boundary), in UTM 49S southern 
hemisphere with WGS 1984 datum covering $4 \times 5 \mathrm{~km}^{2}$ or $20 \mathrm{~km}^{2}$ research area.

\subsection{Regional Physiography}

The research area included eastern Java's physiography based on the physiographic zones by van Bemmelen (1949). Kendeng Zone range has $250 \mathrm{~km}$ and a maximum width of $40 \mathrm{~km}$ (De Genevraye and Samuel, 1972). It stretches from the Ungaran volcano in the west to the east of Java without a clear boundary (van Bemmelen, 1949). The research area is located in the middle of the Kendeng Zone, more precisely on the Pandan Mount slope.

\subsection{Regional Stratigraphy}

Based on some previous research (Harsono, 1983 dan van Bemmelen, 1949), the stratigraphic sequence of the Kendeng Zone is Pelang Formation, Kerek Formation, Kalibeng Formation, Klitik Formation, Sonde Formation, Pucangan Formation, Kabuh Formation, Notopuro Formation, and Quaternary deposits. The primary references for compiling Kendeng's stratigraphy are the publication of De Genevraye and Samuel (1972) and (Harsono, 1983). The Kendeng Zone's stratigraphy is a deep-water deposit at the bottom, increasingly turning upward into shallow marine deposits and eventually becoming non-marine deposits. Deposits in the Kendeng Zone are comprised of clastic, carbonate, and volcaniclastic deposits.

The regional stratigraphy that included in the research area from is Kerek Formation (Tmk), Kalibeng Formation (Tmpk), Atasangin Member Kalibeng Formation (Tpka), Klitik Formation (Tpk), Sonde Formation (Tpso), Pucangan Formation (QTp), intrusive rocks (Qia) and alluvium (Qal). Tmk consists of an alternation of sandstone, claystone, tuff, marl, and limestone. Tmpk consists of marl, locally with intercalations of tuff, tuffaceous sandstone, and calcarenite. Tpka consists of tuffaceous sandstone and breccia, with marl, claystone, and silt intercalation. Tpk consists of clastic limestone, with marl and claystone intercalation. Tpso consists of an alternation of claystone, tuffaceous sandstone, and limestone intercalation. Qtp consists of breccia and tuffaceous sandstone. Qia con- sists of pyroxene andesite. Qal consists of clay, sand, gravel, and pebble.

\subsection{Regional Geological Structure}

According to Pulunggono and Martodjojo (1994) in Bachri (2014), there are three dominant structural pattern directions in Java, i.e., Meratus, Sunda, and Java trends. The research area has a Meratus trend with a NE-SW direction. The subduction formed the pattern at the southeast of Sundaland in the late Cretaceous. The research area also has a Java trend with a W-E direction (Hall, 2009). The Java trend slightly has WNW-ESE because Pandan Mount blocks its grooves.

\section{Methodology}

In general, stratigraphic analysis is carried out in five stages: location determination, path planning, measuring stratigraphy with the Jacob stick method, lithological column depiction, and interpretation. This stage began with determining the research location and then collecting secondary data in the form of previous research reports, topographic maps, DEM (Digital Elevation Model) maps (2015), regional geological maps (1992) scale of 1:100,000, and other library sources. This secondary data collection aims to find a general description of the research area and analytical material to determine hypotheses such as tentative geological maps, distribution patterns maps, tentative geomorphological maps, and trajectory maps. Second, path planning can be determined after reconnaissance. The path must have continuous outcrops. If there are continuous outcrops, they can be substituted by a cross-section path. Third, measuring stratigraphy using Jacob Stick. Jacob Stick is used to measure the accurate thickness and dip of the outcrops. Jacob stick is relatively short so that the outcrop thickness can be measured immediately without any slope correction. Fourth, lithological column depiction uses scale 1:200 to give quite a broad image of the stratigraphy. The column's stratigraphic information is a site, thickness, lithology, grain size, fossil, strike-dip, sedimentary structure, description, and facies: fifth, the interpretation of the sample taken and making a correlation.

In this research, rock samples were taken for eleven petrographic analyses (Kerr, 1959) and 


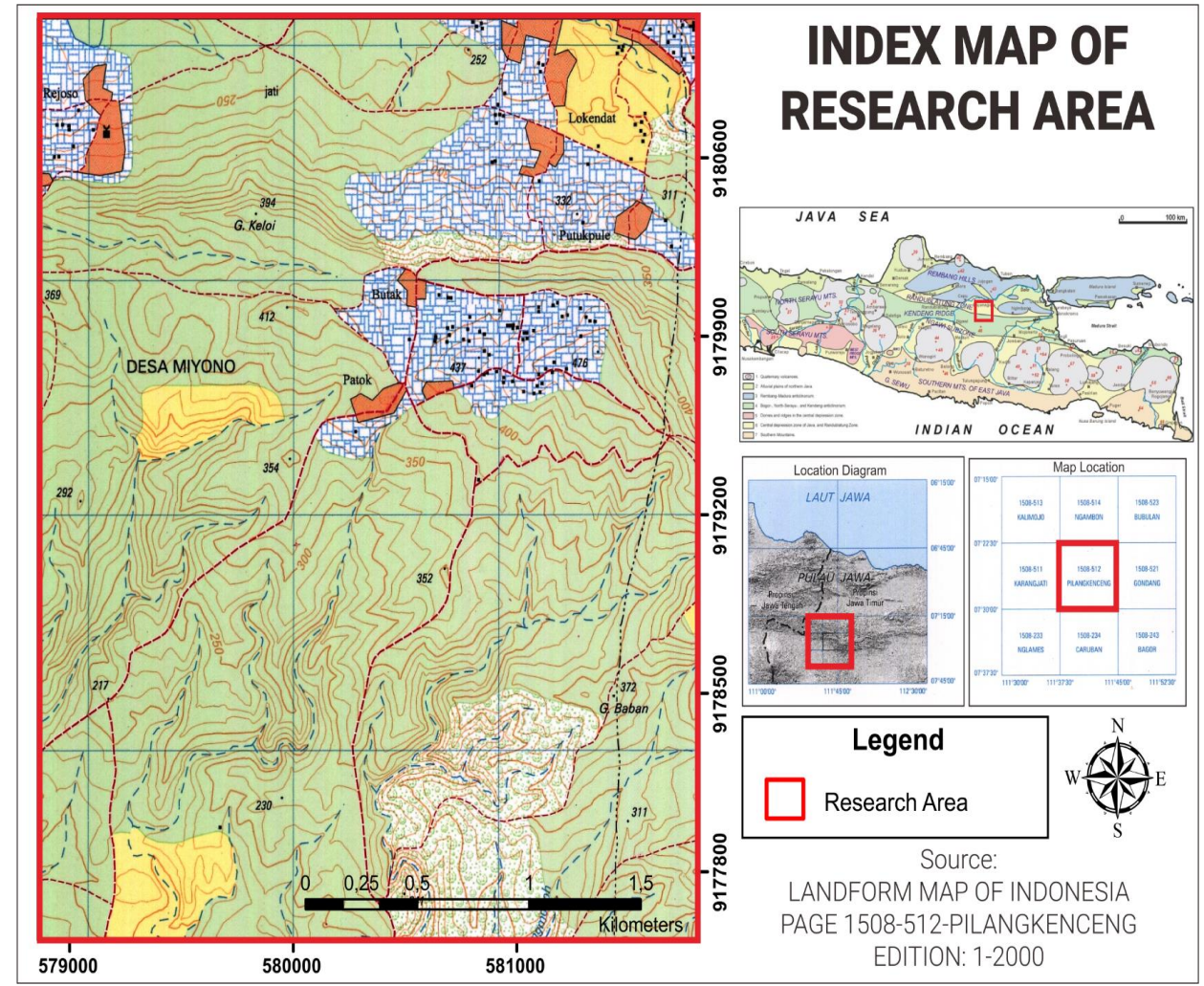

FIGURE 1. Index map of the research area. The location is East Java Province, Pilangkenceng Sheet Number 1508-512 (Blom Narcon Cooperation, 1999).

six paleontological analyses. The Petrographic and paleontological sampling was done by systematically taking rock samples on the bottom and top in each lithology type observed in the field. This method is chosen to see the grain size's continuity from the bottom to the top for sedimentary rock and the rock ages. In carrying out petrographic analysis, the thin section sample is named using several classifications, i.e., limestone-based on the Embry and Klovan (1971), siliciclastic sedimentary rocks based on the classification of Pettijohn (1975), and mixed siliciclastic rocks based on Mount (1985). Meanwhile, paleontological analysis is carried out using the sieve method and petrographic thin sections to observe foraminifera fossils based on the Manual of Planktonic Foraminifera (Postuma, 1971) and Atlas of Benthic Foraminifera (Holbourn et al., 2013). This analysis was used in correlating the rock on regional geology and regional mean sea level. The results were obtained by determining the age, depositional environment (carbonate refers to Wilson (1975) in Nichols (2009); non-carbonate refers to Fisher (1960), Mutti and Ricci Lucchi (1978)), stratigraphic relationships among each line section of each rock unit as well as the reconstruction of geological history. Thus, this research provides a comparison of interpretation results with regional geology and regional mean sea level.

\section{RESULTS}

The research used eleven petrographic thin sections and six paleontological sieve samples (Figure 2). The stratigraphic column shows the rock distribution and petrographic and paleontological sampling location (Figure 3). The Stratigraphic of research areas was arranged based on the lithostratigraphy that can be observed and objectively differentiated in the field. The physical features that can be observed are the texture, structure, and composition of the rock. Besides, petrographic analysis supported the lithostratigraphy analysis. Furthermore, determining the lithostratigraphic units and depositional environments were determined through paleontological analysis and regional stratigraphy correlations.

The geological maps obtained from fieldwork results were used to draw the lithology unit boundaries (Figure 4). The determination of clear boundaries was based on rock 


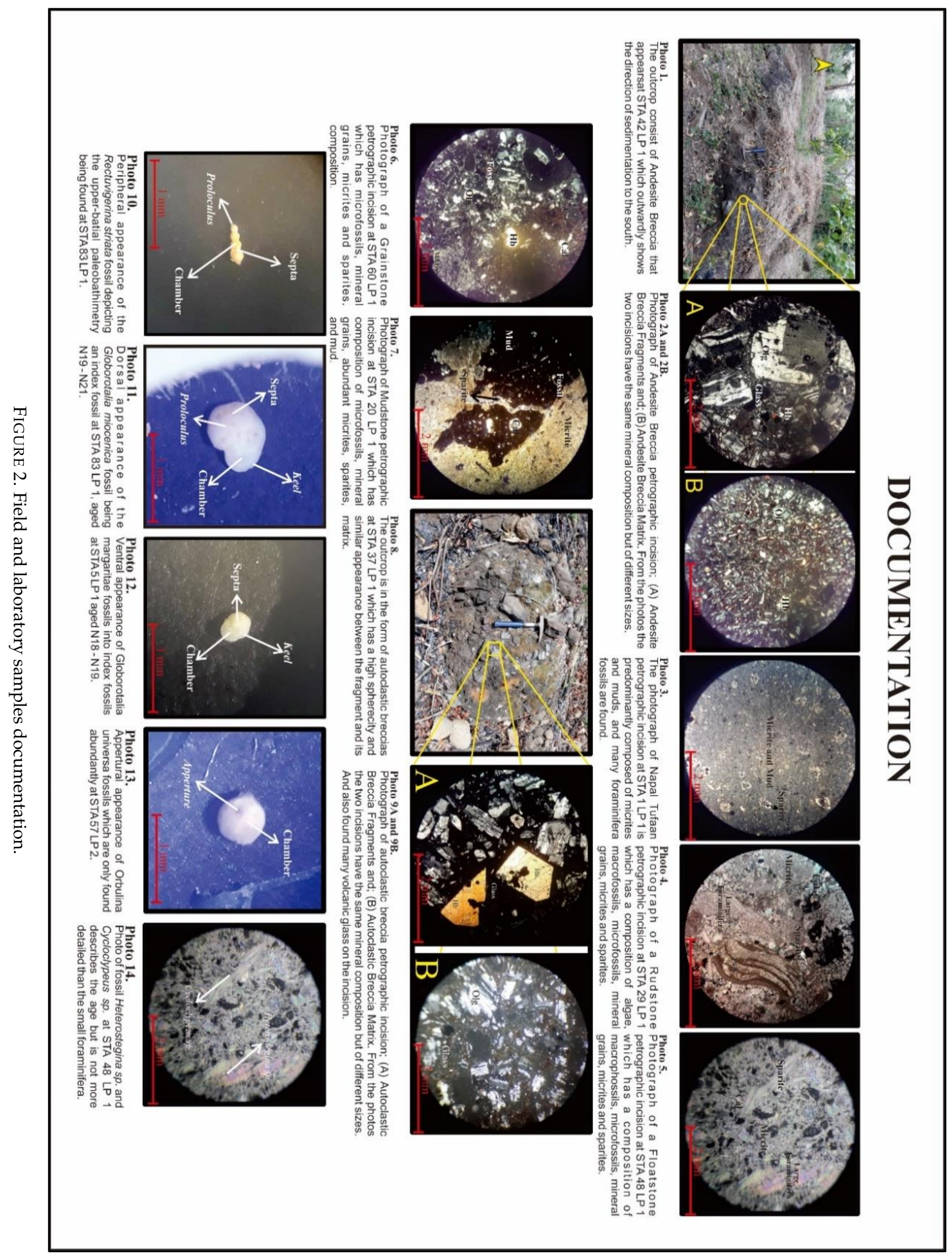


Stratigraphy of Kendeng Zone in Miyono Village And Surrounding AREAS SEKAR District

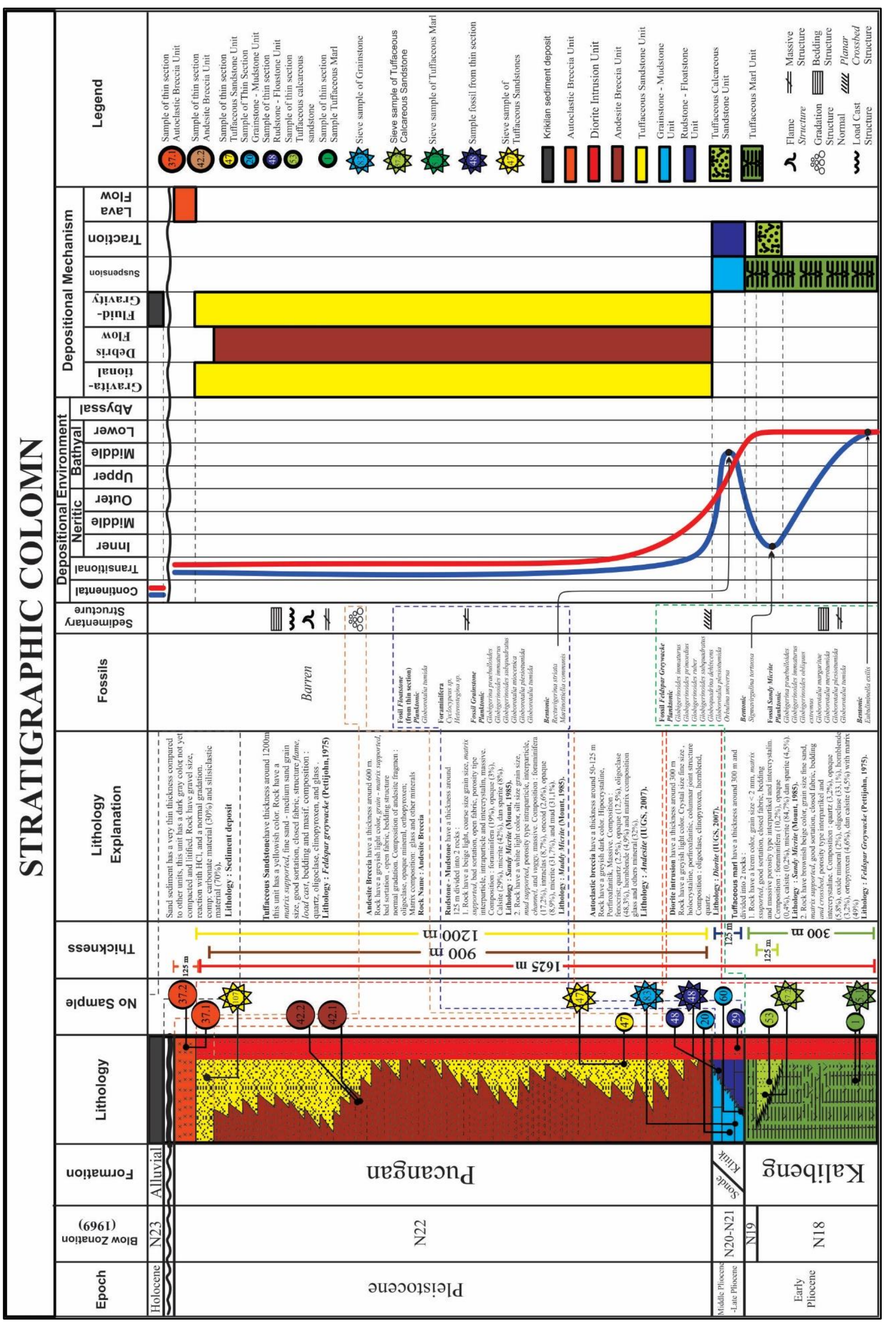

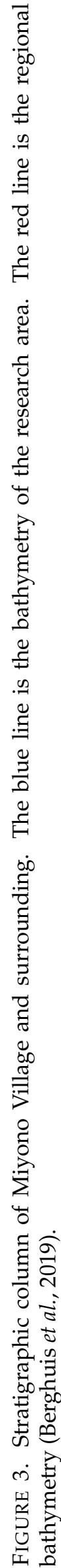


contacts and interpretation results. The order of rock units and their relationship can be seen in geological sections. The research area's stratigraphy can be divided into nine lithology units. It is a tuffaceous marl unit from oldest to youngest, a tuffaceous calcareous sandstone unit, and rudstone-floatstone unit, a grainstone-mudstone unit, andesite breccia unit, tuffaceous sandstone unit, diorite intrusion unit, autoclastic breccia units, and Krikilan sediment deposit.

\subsection{Tuffaceous marl unit}

The tuffaceous marl unit (Figure 5A) is the oldest in the research area. This unit spreads evenly in the northern part and the fold valley morphology, Miyono Village, Sekar, Bareng, Bobol, Sekar District. In addition, a tuffaceous calcareous sandstone unit was inserted into this unit. It was known from the change in grain size directly in the eastern part of the research area, while the lower part of this unit is unknown yet.

This unit comprises dominant volcanic glass and well-sorted carbonate. Based on the structure and texture, it can be interpreted that this unit is deposited in a deep marine environment. Many fossils were found from paleontological observation, i.e. Globigerinoides praebulloides, Globigerinoides immaturus, Globigerinoides obliquus extremus, Globorotalia margaritae, Globorotalia merotumida, Globorotalia plesiotumida, and Globorinoidia tumida. Furthermore, based on the fossils, it can be interpreted that this unit was deposited in the lower to middle bathyal.

\subsection{Tuffaceous calcareous sandstone unit}

The tuffaceous calcareous sandstone unit (Figure 5B) was formed due to the relative sea-level regressions and conformable with the tuffaceous marl unit. It spread in the west-central part precisely in the Sekar and Miyono Village, Sekar District, and thinned to the east.

The tuffaceous calcareous sandstones are inserted into the tuffaceous marl unit. This unit is composed of high volcanic material. This unit also shows the existence of tuff due to its light rock mass. This unit has a parallel crossbedding sedimentary structure. Many fossils were found from paleontological observation, i.e., Globigerinoides immaturus, Globigerinoides primordius, Globigerinoides ruber, Globigerinoides subquadratus, Globoquadrina dehiscens, Globorotalia plesiotumida, and Orbulina universa. Based on the fossils, it can be interpreted that this unit was deposited in inner neritic.

\subsection{Rudstone-floatstone unit}

The rudstone unit (Figure 5C) is thickening to the west. This unit spreads to the west around Sekar Village, Sekar District. It is conformable with the lithologies below and above it. It is called a rudstone-floatstone unit because the dominant lithology is spreading over this unit.

This unit was formed in minor volcanic activity. The lithology in this unit is dominated by limestone with compositional carbonate material $>2 \mathrm{~mm}$ in size that intersects each other, named rudstone (Embry and Klovan, 1971), and some of that do not intersect, named floatstone (Embry and Klovan, 1971). The paleontological observation analysis discovers the large macrofossils foraminifera, i.e., Cyclocypeus sp., and Heterostegina sp. In addition, this unit also contains microfossils foraminifera discovering from petrographic thin sections, i.e., Globorotalia tumida. Those fossils show a neritic depositional environment.

\subsection{Grainstone-mudstone unit}

Grainstone-mudstone unit (Figure 5D) is a unit that is interfingering-deposited with a rudstone-floatstone unit. This unit spreads out in the middle of the research area around Bobol Village, Bareng Village, Miyono Village, Sekar District. It is conformable with the older and younger lithologies. This unit consists of lithologies in grainstone-mudstone without any clear boundaries between lithologies (Embry and Klovan, 1971).

This unit consists of lithologies in the form of limestone with a composition of material $>2$ $\mathrm{mm}$, grain supported to matrix-supported. One half contains lime mud named mudstone, and the other does not have lime mud named grainstone (Embry and Klovan, 1971). Paleontological observation discovers many fossils, i.e. Globigerina praebulloides, Globigerinoides immaturus, Globigerinoides subquadratus, Globorotalia miocenica, Globorotalia plasiotumida, and Globorotalia tumida. This unit's paleobathymetry zone 


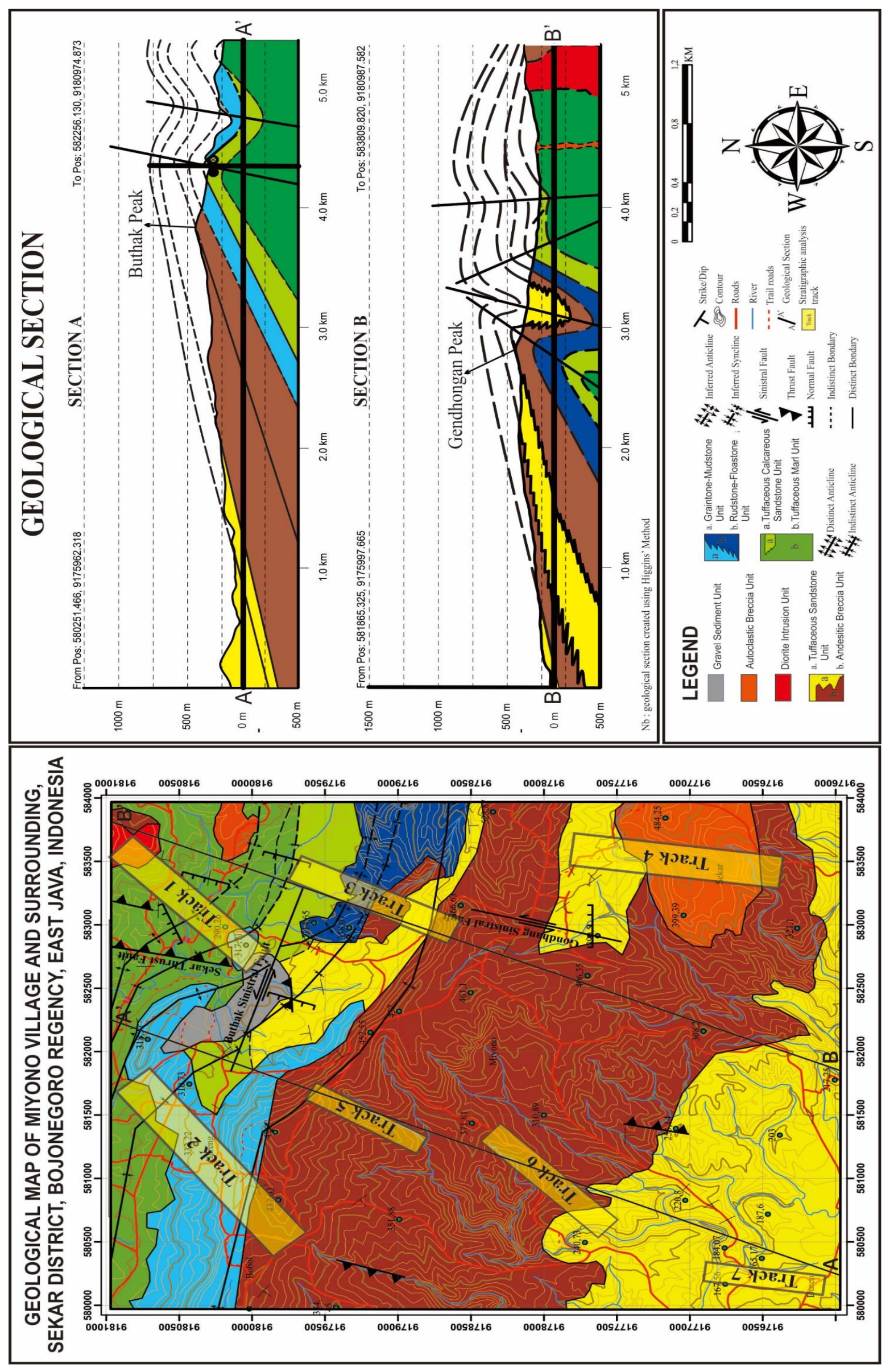

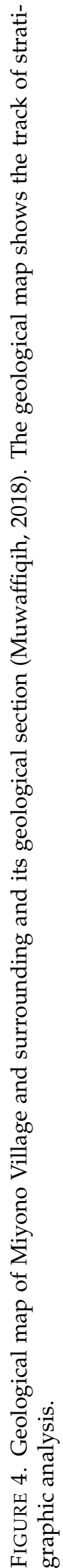



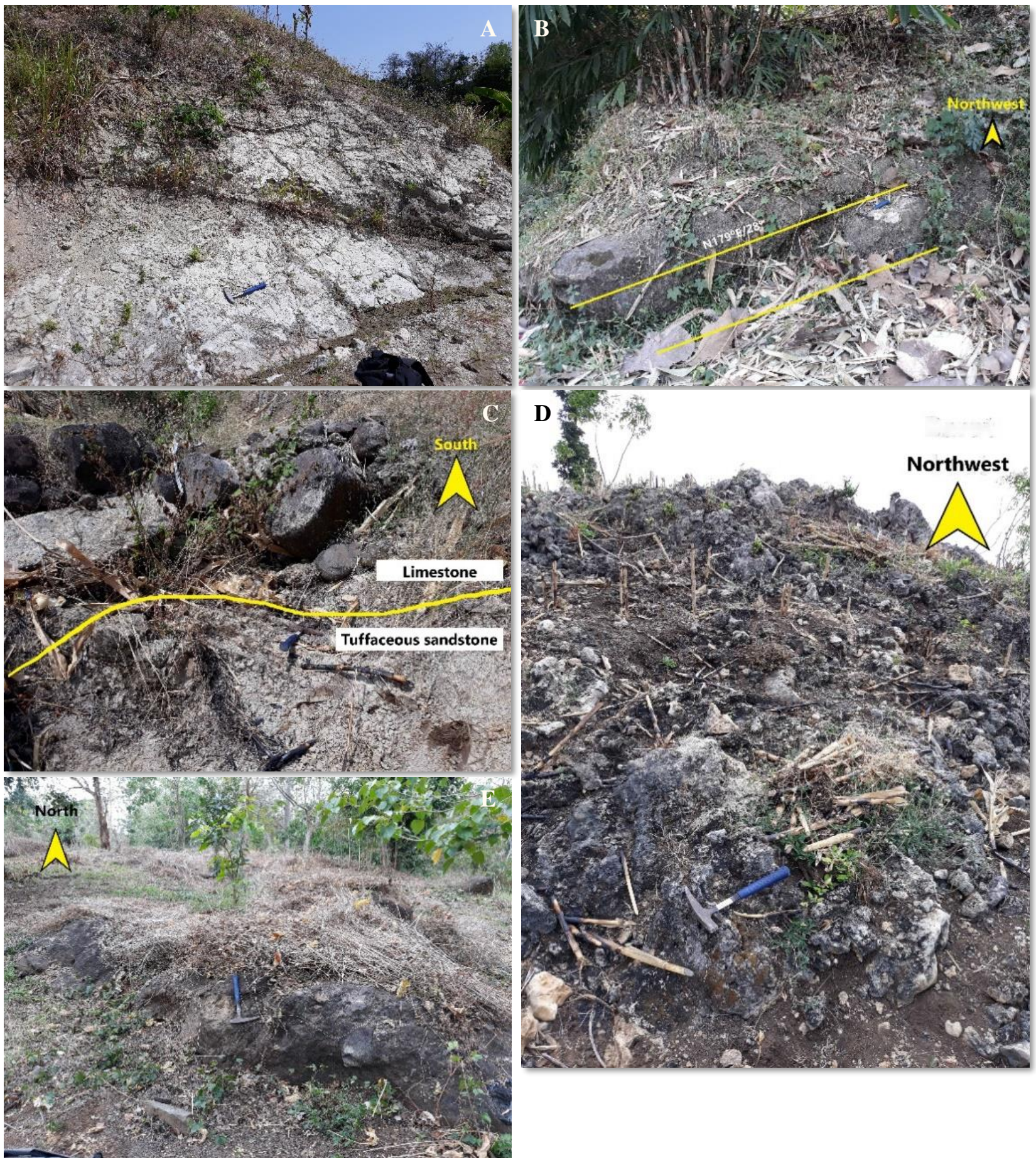

FIGURE 5. (A) The outcrop of tuffaceous marl unit on point station 57. The picture shows a fault cutting the outcrop and a lot of joint (hammer handle points north). (B) The outcrop of tuffaceous calcareous sandstone on point station 1 . The outcrop shows the bedding plane $\mathrm{N} 179^{\circ} \mathrm{E} / 28^{\circ}$. (C) The outcrop of contact lithology between limestone and tuffaceous sandstone at point station 29. (D) The outcrop of grainstone-mudstone unit at point station 48. (E) The outcrop of andesitic breccia at point station 41. 
is determined from the benthic fossils found, i.e., Rectuvigerina striata and Martinottiella communis. Those benthic fossils show middle bathyal. In addition, those benthic fossils show that the bottom part of the grainstonemudstone unit was deposited in the deep marine environment. This environment is the transition of the tuffaceous marl unit to the grainstone-mudstone unit.

\subsection{Andesite breccia unit}

The andesite breccia unit (Figure 5E) is deposited conformably on the rudstonefloatstone and grainstone-mudstone units and is interfering-deposited with the tuffaceous sandstone unit. This unit spreads in the middle and extends to the southern part of the research area around the Bobol, Bareng, Miyono, Sekar Village, Sekar District, and thickening to the west.

The lithology in this unit is andesite breccias with the composition of andesitic fragments and matrices containing glass material, grain supported, and having a normal chaotic gradation structure. The analysis of paleontological samples shows no fossil (barren) found at the bottom of the unit, so the age of the unit's lower boundary is determined by using a comparability column.

\subsection{Tuffaceous sandstone unit}

The andesite breccia unit (Figure 6F) is a unit that is deposited conformably above the andesite breccia unit and interfingering-deposited with the andesite breccia unit, which thickens to the east. This unit is scattered in the middle, extending to the south of the research area around the Bobol, Bareng, Miyono, and Sekar Village, Sekar District. It is named tuffaceous sandstone unit because composed of sand-sized grain without carbonate material.

This unit has a material composition with sand and grain supported and has a bedding structure, i.e., crossbed, load cast, and flame. The sedimentary unit source is the same as the andesite breccia unit's source, but the difference is the depositional mechanism and age. This unit was deposited in the transition area. No fossils found (barren) from the paleontological analysis, so the age of the unit's lower bound- ary is determined by using a comparability column

\subsection{Diorite intrusion unit}

This diorite intrusion unit (Figure 6G) is a unit that broke through previous older lithologies. It makes nonconformity contacts with those previous older lithologies. This unit spreads narrowly on the northeast and east sides of the research area, precisely in Miyono Village, Sekar District. It has a trachytic lava texture (McPhie et al., 1993) and no fossil recorded (barren) on petrographic thin sections.

\subsection{Autoclastic breccia unit}

The autoclastic breccia unit (Figure $6 \mathrm{H}$ ) is a unit deposited conformably above the tuffaceous marl unit and aligned above the andesite breccia unit, thickening to the west. This unit spreads out in the east and spreads to the west of the research area around Sekar Village, Sekar District. It is called an autoclastic breccia unit because it has the same material composition between the fragment and the matrix.

This unit is formed from the freezing flow of lava on the surface, flowing from east to west. This unit was deposited in the terrestrial environment and can be seen in the stratigraphic column. There is no fossil (barren) found at the unit's bottom from the paleontological sample analysis.

\subsection{Pebbly sediment deposit}

Pebbly sediment deposit (Figure 6I) is deposited unconformably over the tuffaceous marl and tuffaceous calcareous sandstone units. This unit spreads out in the middle of the research area in Miyono Village, Sekar District. The deposit is the result of weathering and erosion of the surrounding grainstone. This unit has a material composition with the characteristics, i.e., sand-sized particle, grain supported, massive structure, and laminated. The source of this sediment is the grainstone in surrounding areas.

All lithologies of the research area are compiled into one single stratigraphic arrangement (Figure 7). Then, it will be compared with the regional stratigraphy of Miyono and its surrounding. The recorded stratigraphy shows the differences with the regional stratigraphic map, 

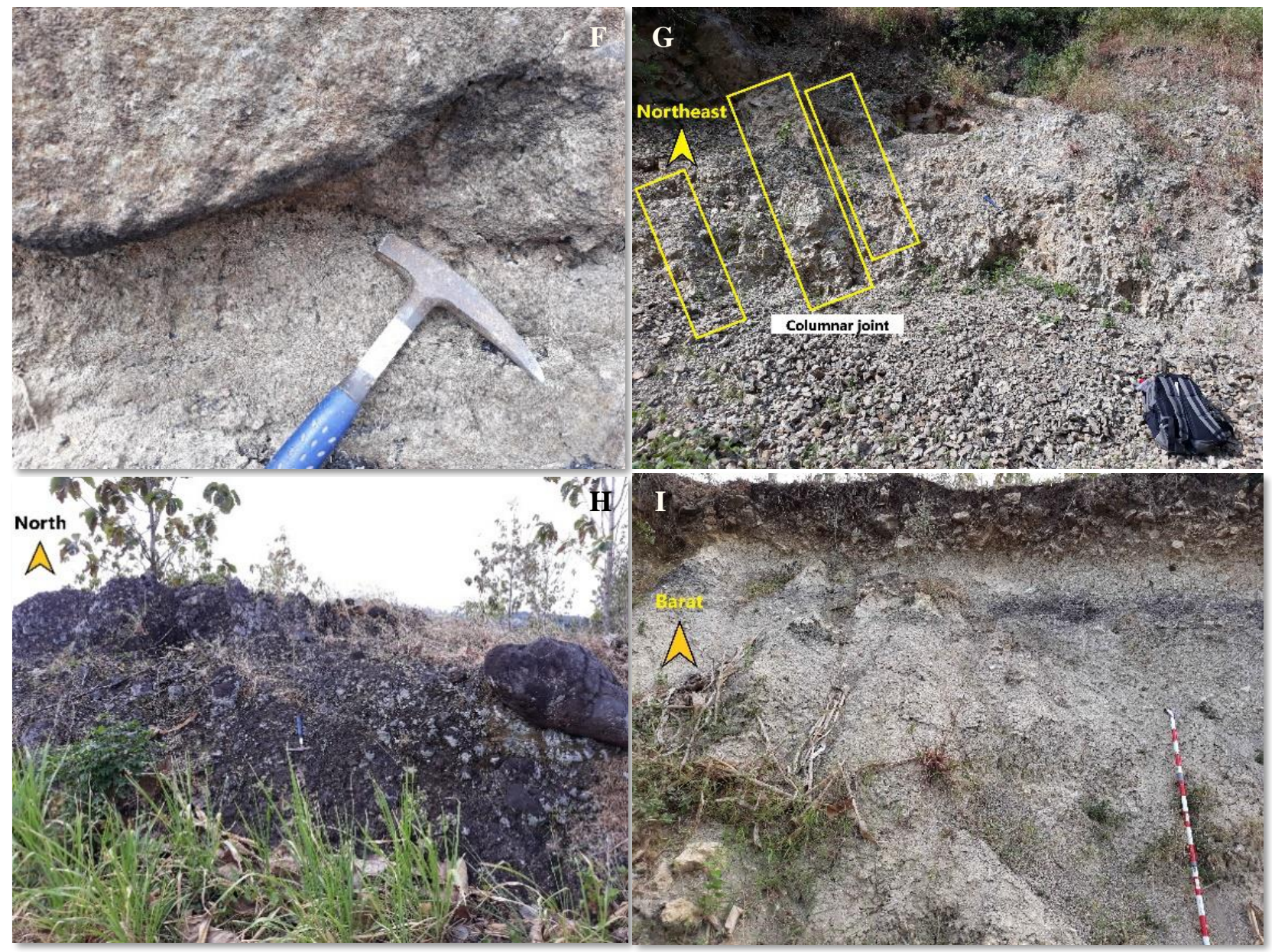

FIGURE 6. The crossbed sedimentary structure of tuffaceous sandstone at point station 148 (hammer handle points north). (G) The outcrops of diorite intrusion with columnar joint structures at point station 2. $(\mathrm{H})$ The outcrop of autoclastic breccia at point station 39. The outcrop shows the flow of ancient magma to the southeast. (I) The outcrop of pebbly sediment deposit at point station 76 . 
including the lithological boundaries, the lithology on site, and the geological structures.

\section{Discussion}

The field result and interpretation compared with regional geology (Figure 8) show some glaring differences. The regional stratigraphy contains Kerek Formation (Tmk), and Atasangin Member of Kalibeng Formation (Tpka), while the result of this research revealed that the area does not have those formations. Kerek formation (Tmk) is estimated to be located deeper and not revealed to the surface. In contrast, Atasangin, a Member of the Kalibeng Formation (Tpka), may be located further north of the research area. The Kalibeng Formation was composed of tuffaceous marl and tuffaceous calcareous sandstone with diorite intrusion in the northeast area. Diorite intrusion could be a breakthrough due to increased tectonism activity during Pleistocene (N22), causing rocks to be shaken so that magma activity increases and can break through the existing fracture pressure differences. A magma will break through the opening with the smallest pressure. This diorite intrusion broke through the older rocks based on the comparability column (Figure 9), but the diorite intrusion with other rocks in that place was eroded so massively that it seemed to be found in older rocks or with Kalibeng Formation. The thickness of the Kalibeng Formation (Tmpk) is estimated at 300 meters or could be more. Klitik Formation (Tpk) was found \pm 125 meters thick with lithologies arrangement consists of rudstone, floatstone, and grainstone.

In contrast, Sonde Formation (Tpso) was found \pm 125 meters thick with finer grain limestone arrangement, packstone, wackestone, and mudstone. The limestone's material source came from the carbonate factory located further east of the research area. The interfingering andesite breccia with tuffaceous sandstone was found \pm 1200 meters composing Pucangan Formation (QTp). Compared with regional geology, the result shows the lithologies composing all formations located further north. So, the formation's border is also found further north from the location stated in the regional geology of the Bojonegoro Regency. Another difference is the boundary between Klitik Formation (Tpk) and Sonde Formation (Tpso). The

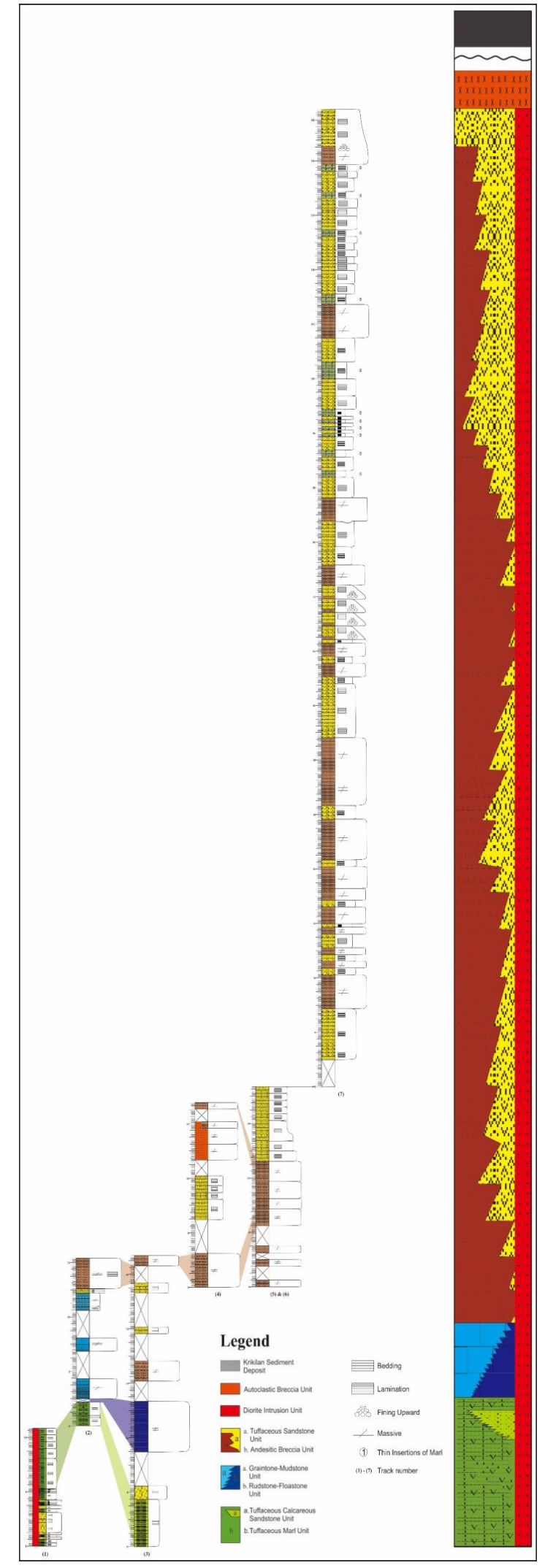

FIGURE 7. Combined stratigraphy of the entire sections (scale 1:200, except the blank zone, scale 1:2000) and the research area's composite stratigraphy in a single column (right column). The composite stratigraphy picture shows the depositional direction and source origin. 


\section{The Regional Geological Map of Research Area}
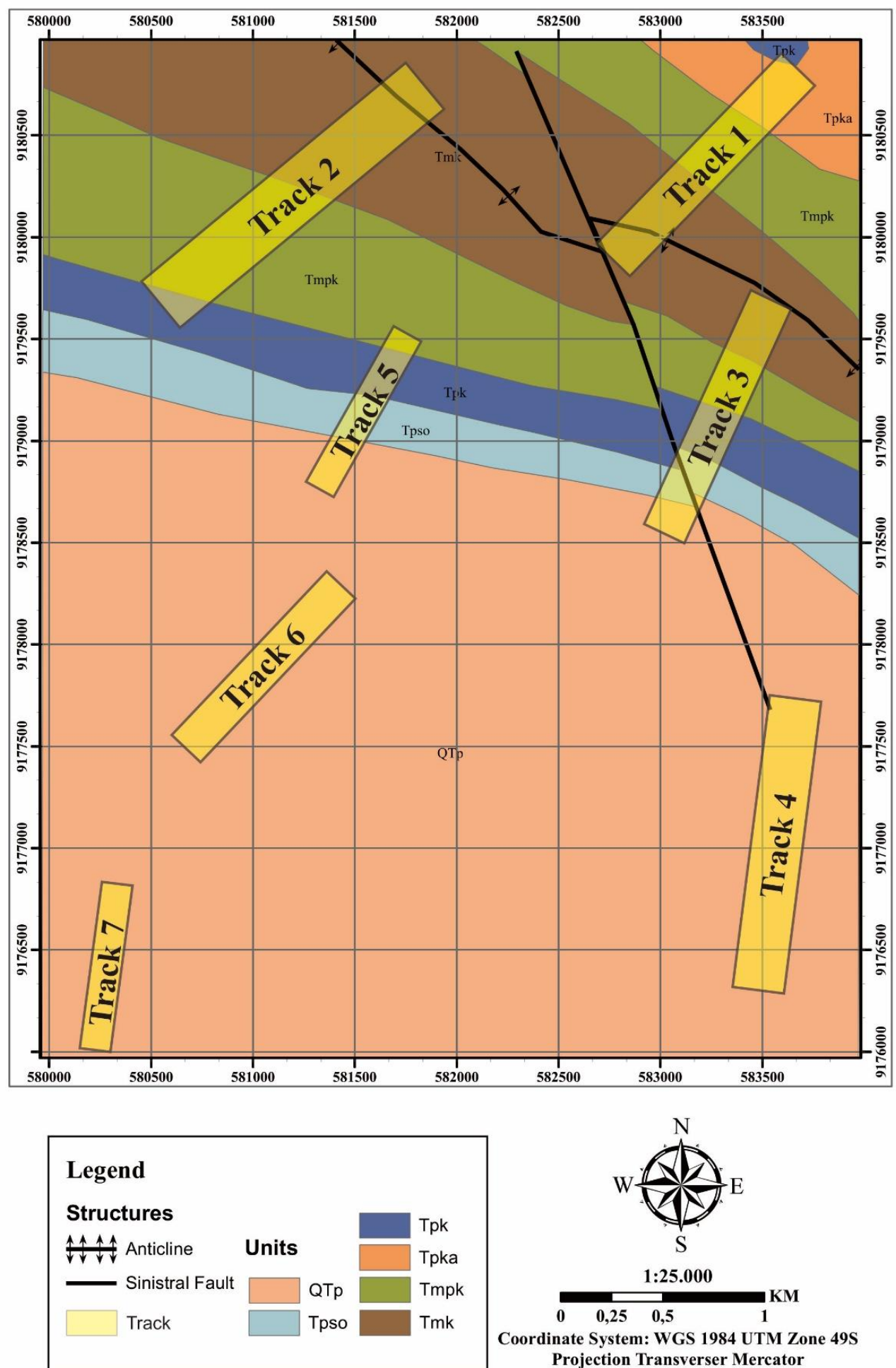

FIGURE 8. The regional stratigraphy of Miyono Village and surrounding. The map shows six formations and two main geological structures (Pringgoprawiro and Sukido, 1992). The regional geological map shows the track of stratigraphic analysis. 


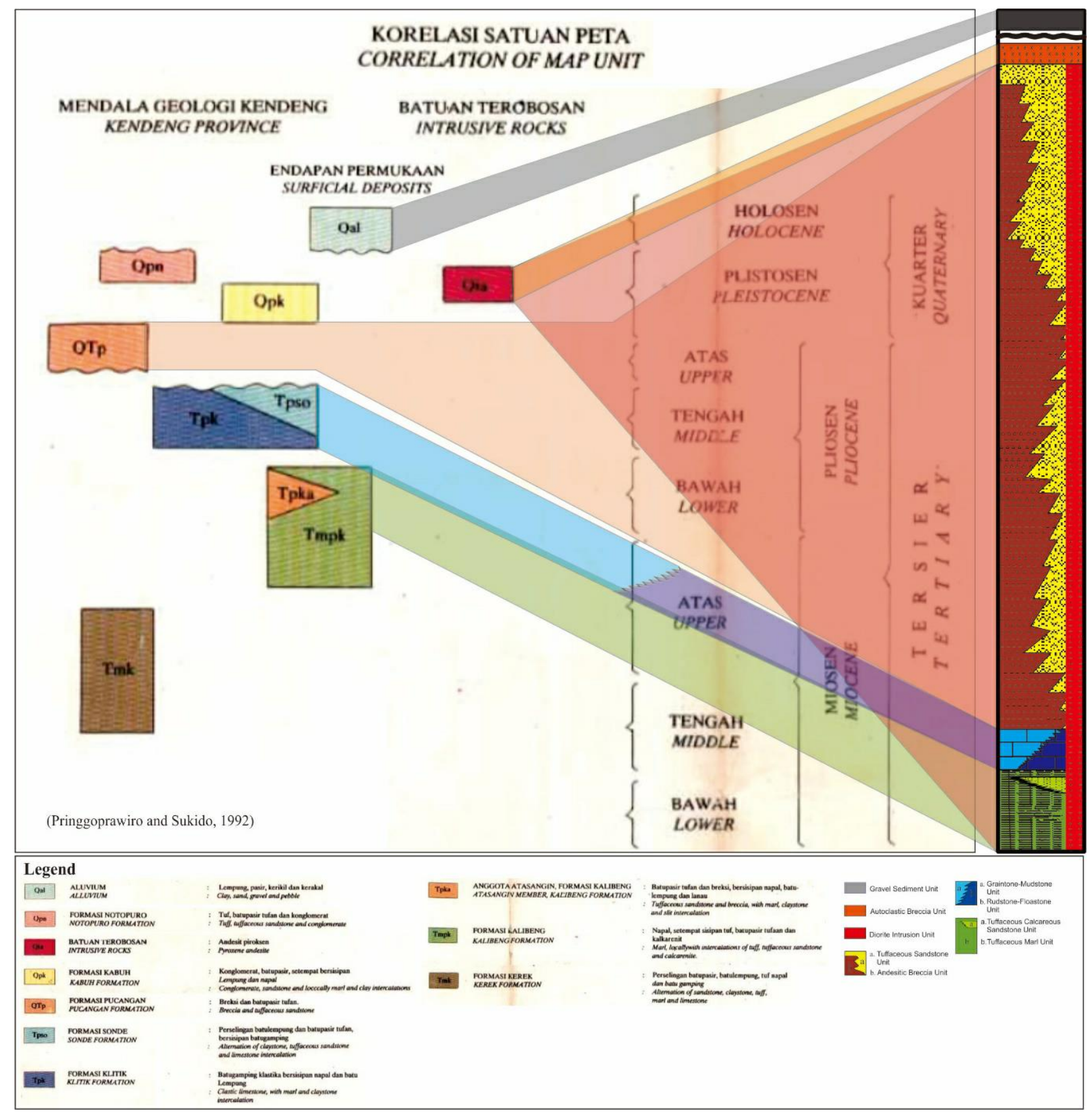

FIGURE 9. Comparability column (not scaled) of Kendeng Zone (Pringgoprawiro and Sukido, 1992) compared to the stratigraphy of Miyono Village and its surrounding (right column). 
regional geology shows the north-south trending boundary, but the result shows east-west trending with no firm boundary. Therefore, the stratigraphy arranged by considering structures will be formed like Figure 4(right).

Each lithology's age is determined using planktonic foraminifera, the planktonic fossils found at the bottom and top of the tuffaceous marl, making each different epoch. The bottom of the tuffaceous marl has N18, while the top has N19, and both were formed in the early Pliocene epoch. Planktonic foraminifera found at the bottom of limestone or mudstone and the top of limestone or floatstone shows the middle Pliocene's epoch range - late Pliocene (N20-N21). Both fossils found in floatstone were coming from the petrographic thin sections. The problem arose when no fossils were found in andesite breccia, tuffaceous sandstone, diorite intrusion, and autoclastic breccia. Hence, the age of andesite breccia, tuffaceous sandstone, diorite intrusion, and autoclastic breccia were determined using the comparability column. Based on the comparability column (Figure 9), andesite breccia and tuffaceous sandstone are comparable to Pucangan Formation with Pleistocene epoch (N22). In contrast, diorite intrusion and autoclastic breccia are comparable to Intrusive Rock (Qia). Krikilan sediment deposit is included as the alluvial deposit with the Holocene epoch (N23). The comparability column also shows the same result compared with the non-barren lithologies. The non-barren lithologies are located following the comparability column, precisely on N18-N21.

Based on paleontology and lithology, all the sediments formed in a marine environment. Kalibeng Formation deposited on the deep shallow marine environment or ranged between middle bathyal - inner neritic. Kalibeng Formation experienced a rapid change in sea level or accommodation space. It was lower bathyal at the bottom part and became inner neritic in the middle part (tuffaceous calcareous sandstone). It was turning into a middle bathyal at the upper part. Tuffaceous calcareous sandstone was formed in inner neritic identified from its parallel crossbed structure and fossils. This structure indicates sea-level regression. Due to being affected by waves, this causes a traction mechanism. This parallel crossbed structure indicates that the strength of the wave at that time. Tuffaceous calcareous sandstone has sourced from the east area, which means the east of the research area ever became inner neritic while the west area was still bathyal. The change of the depth rapidly is estimated because of the local uplift in the east. As the local uplift stopped, the depositional environment was returning to bathyal again. It means the tectonic event in this epoch was very active. Klitik and Sonde Formation were formed in outer - inner neritic. The carbonate factory is found in the east of the research area. Hence, the limestone's grain size in Klitik and Sonde is roughened to the east, meaning the sea level became shallower.

Based on (Wilson 1975) in Nichols (2009), the rudstone-floatstone depositional environment is in the slope area. The lithology shows the presence of sea-level drop, which means the environment was getting shallower. Pucangan Formation was formed in the transitional zone. During the deposition of the Pucangan Formation, additions and subtractions of sediment supply occurred, which was proven by the existence of calcareous siltstone. The calcareous siltstone will be replaced by tuffaceous sandstone and andesite breccia when the sediment supply was high. The material supplies came from the volcanic activity in the western part of the area. Based on this lithology, it can be interpreted that the lithology originated from explosive volcanism. It might be Mount Wilis which is the nearest active volcano in the research area. This unit was deposited when there was a massive regression of relative sea levels. Based on the structure formed, this unit was created through debris flow to form a chaotic formation (Fisher, 1966). The normal gradation structure was formed due to the reduced supply of sediment- correlated with the decreased activity of Wilis Volcano. Tuffaceous sandstone unit laid on the andesite breccia unit. Based on the structure formed, the tuffaceous sandstone was formed through gravitational and fluidgravity mechanisms. The gravitational mechanism characterizes the depositional mechanism of volcaniclastic material. Fluid-gravity characterizes the depositional mechanism of siliciclastic material due to surface water flow. Sed- 
imentary structures in this unit were formed due to fluid gravity. This unit is indirectly sourced from the Wilis volcano's volcanic material but from another deposit whose source also came from the Wilis volcano so that it can form a stratigraphic cross-section showing middle fan (Mutti and Ricci Lucchi, 1978). The youngest unit is the Krikilan sediment deposit with the primary depositional mechanism by fluid-gravity, which characterized surface water flow and indicated terrestrial environment.

Compared with the regional mean sea level (Berghuis et al., 2019), the research area has an anomaly (Figure 3). The research area has significant shallowing and deepening events from lower bathyal became inner neritic in Early Pliocene (N20) and became upper bathyal in Early Pliocene (N19). This might happen because of the active volcanism around the area. At the same time, the regional bathymetry shows no significant bathymetry changes. This might happen due to the Kendeng Zone located in the central deep of North Java Basin. In Late Pliocene, the sea level regression might occur due to the local uplift in the very active tectonic epoch. Then in the Pleistocene, the area became a transition environment because the uplift was ongoing. Thus, the research area has a quite different bathymetry in Early Pliocene and relatively same bathymetry in Late Pliocene to Holocene.

\section{CONCLUSION}

Based on the analysis, stratigraphy of Miyono and its surrounding can be concluded from the oldest to the youngest are: 1) Tuffaceous marl unit; 2) Tuffaceous calcareous sandstone unit; 3) Rudstone-floatstone unit; 4) Grainstonemudstone unit; 5) Andesite breccia unit; 6) Tuffaceous sandstone unit; 7) Diorite intrusion unit; 8) Autoclastic breccia unit; and 9) Pebbly sediment deposit. These stratigraphic units are included in Kalibeng Formation, Klitik Formation, Sonde Formation, Pucangan Formation, and alluvial (Harsono, 1983 in Pramono and Amijaya, 2008).

Sea level regression occurs during the early Pliocene (N18) until Holocene (N23). The bathymetry was from lower bathyal to terrestrial-based by paleontology and lithology analysis. The significant differences between regional mean sea level and local mean sea level are estimated can be caused by the active local volcanism. The depositional mechanism that formed the lithologies were lava flow, traction, suspension, flow gravity, debris flow, and gravitational, which occurred in the region.

\section{ACKNOWLEDGEMENTS}

The authors would like to thank Athifah Rosyidah for her advice and assistance in grammar check.

\section{REFERENCES}

Bachri, S., 2014. The Effect of Regional Tectonics to the Structural Pattern and Tectonics of Java Island. Journal of Geology and Mineral Resources $15,7$.

Berghuis, H.W.K., Troelstra, S.R., Zaim, Y., 2019. Plio-Pleistocene foraminiferal biostratigraphy of the eastern Kendeng Zone (Java, Indonesia): The Marmoyo and Sumberingin Sections. Palaeogeography, Palaeoclimatology, Palaeoecology 528, 218-231. DOI: 10.1016/j.palaeo.2019.05.008.

Blom Narcon Cooperation, 1999. Peta Rupa Bumi Digital Indonesia 1:25.000 Lembar 1508-512 Pilangkenceng. De Genevraye, P., Samuel, L., 1972. Geology of the Kendeng Zone (Central and East Java). IPA 17-30.

Embry, A.F., Klovan, J.E., 1971. A Late Devonian Reef Tract on Northeastern Banks Island, N. W. T. Bulletin of Canadian Petroleum Geology 19, 731781. DOI: 10.35767 /gscpgbull.19.4.730.

Fisher, R.V., 1966. Rocks Composed of Volcanic Fragments and Their Classification. EarthScience Reviews 1, 287-298. DOI: 10.1016/00128252(66)90010-9.

Fisher, R.V., 1960. Classification of Volcanic Breccias. GSA Bulletin 71, 973-982. 10.1130/00167606(1960)71[973:COVB]2.0.CO;2

Hall, R., 2009. Indonesia, Geology, in Gillespie, R., Clague, D. (Eds.), Encyclopedia of Islands. University of California Press, Berkeley, California, pp. 454-460.

Harsono, P., 1983. Biostratigrafi dan Paleostratigrafi Cekungan Jawa Timur, Suatu Pendekatan Baru (Doctoral Thesis). Bandung Institute of Technology, Bandung.

Holbourn, A., Henderson, A.S., Macleod, N., 2013. Atlas of Benthic Foraminifera, 1st ed. WileyBlackwell, West Sussex.

McPhie, J., Doyle, M., Allen, R., University of Tasmania., Centre for Ore Deposit and Exploration Studies., 1993. Volcanic textures: a guide to the interpretation of textures in volcanic rocks. Centre for Ore Deposit and Exploration Studies, University of Tasmania, Hobart, Tas. 
Mount, J., 1985. Mixed siliciclastic and carbonate sediments: a proposed first-order textural and compositional classification. IAS 32, 435-442. DOI: $10.1111 /$ j.1365-3091.1985.tb00522.x.

Mutti, E., Ricci Lucchi, F., 1978. Turbidites of the northern Apennines: Introduction to facies analysis. International Geology Review 20, 125-166. DOI: $10.1080 / 00206817809471524$.

Muwaffiqih, M.I., 2018. Laporan Pemetaan Geologi Mandiri Geologi Daerah Miyono dan Sekitarnya, Kecamatan Sekar, Kabupaten Bojonegoro, Jawa Timur.

Nichols, G., 2009. Sedimentology and Stratigraphy, 2nd ed. ed. Wiley-Blackwell, Chichester, UK; Hoboken, NJ.

Pettijohn, F.J., 1975. Sedimentary Rock, 3rd ed. Harper and Row, California.
Postuma, J.A., 1971. Manual of Planktonic Foraminifera. Elsevier Publication Company, Amsterdam.

Pramono, W., Amijaya, H., 2008. Karakteristik Geokimia Rembesan Minyak Bumi di Daerah Bantal, Kecamatan Bancak, Semarang, Jawa Tengah. Prosiding PIT IAGI, 3714.

Pringgoprawiro, H., Sukido, 1992. Peta Geologi Lembar Bojonegoro Jawa Timur.

van Bemmelen, R.W., 1949. The Geology of Indonesia. Vol. 1A. General Geology of Indonesia and Adjacent Archipelagoes. Government Printing Office, The Hague.

Wilson, J.L., 1975. Carbonate Facies in Geologic History, 1st ed. Springer-Verlag, New York. 